\title{
CASTRAÇÃO EM CAPRINOS, NO APRISCO DO INSTITUTO FEDERAL DE CIÊNCIAS E TECNOLÓGIA DO MARANHÃO - CAMPUS CODÓ-MA
}

\section{CASTRATION IN GOATS, AT THE APRISCO OF THE FEDERAL INSTITUTE OF SCIENCES AND TECHNOLOGY OF MARANHÃO - CAMPUS CODÓ-MA}

\author{
Rangel Gandh Cavalcante Lima ${ }^{1}$; João Paulo da Silva Sousa ${ }^{2}$; Daniel Portela Leal ${ }^{3}$; Maria \\ Raimunda da Silva ${ }^{4}$; Glayde Maria Carvalho Véras ${ }^{5}$.
}

DOI: $\underline{\text { https://doi.org/10.31692/978-65-991061-7-0.490-492 }}$

\section{INTRODUÇÃ̃O}

A criação de ovinos e caprinos no Brasil vem se desenvolvendo em larga escala nos últimos anos, comprovando as previsões de especialistas sobre o potencial dessa atividade, especialmente no Estado de São Paulo. Pesquisa do IBGE (Instituto Brasileiro de Geografia e Estatística) demonstra que o rebanho nacional de ovinos e caprinos somava 25 milhões de cabeças há apenas três anos (2004). Atualmente, já superam 30 milhões de cabeças.

Nesse ritmo, o Brasil já é o $8^{\circ}$ maior criador de caprinos e ovinos no mundo. A maior concentração dos rebanhos está nas regiões Nordeste, com cerca de 50\% dos ovinos e 90\% dos caprinos.

A carne caprina tem grande potencial de consumo em razão de seu valor nutritivo e de sua aceitabilidade. Na produção brasileira, a região nordeste participa com 90\%, concentrando-se os maiores rebanhos nos Estados da Bahia, Piauí e Pernambuco (FAO) [8]. Nas áreas rurais, a caprinocultura constitui uma atividade sócio-econômica de destaque, sendo a principal fonte protéico-alimentar (carne e leite), bem como fonte de renda, através da venda de couro e do excedente de carne.

\section{RELATO DE EXPERIÊNCIA}

O curso de Licenciatura Ciências Agrárias abrange muitas áreas, com isso proporciona aos alunos várias oportunidades, uma dessas foi à participação em aula de castração em caprino, aonde todos teve oportunidade de por em prática o que foi ministrado pelo professor em sala de aula.

A aula pratica feita pelo professor visa demostrar melhor o que foi passado em sala de aula e por em prática o que os alunos aprenderam. Muitos alunos demostraram que

\footnotetext{
${ }^{1}$ Licenciatura em Ciências Agrarias, IFMA- CAMPUS CODÓ, gandhrangel@ gmail.com

${ }^{2}$ Licenciatura em Ciências Agrarias, IFMA- CAMPUS CODÓ, joaopauloneto1.00@ gmail.com

${ }^{3}$ Licenciatura em Matemática, IFMA- CAMPUS CODÓ, daniel.portela@acad.ifma.edu.br

${ }^{4}$ Tecnologia em Alimentos, IFMA- CAMPUS CODÓ, mariaraimundasilva@gmail.com

${ }^{5}$ Professora de Anatomia, IFMA-CAMPUS CODÓ, glaydeveras@ifma.edu.br
} 
aprenderam realmente o que foi passado em aula desde a maneira segura de se conter o animal a campo até os procedimentos da castração cirúrgica, já outros demostraram dificuldades tais quais como receio de realizar a contenção ou da realização do procedimento em si, mas o professor teve a paciente de ensinar a odos os alunos com maior calma o passo a passo da aula.

Imagens 1: Maneira simples e segura de segura o caprino no aprisco, (A); Higienização e tricotomia dos testículos, (B); Incisão horizontal na região ventral dos testículos, (C); Exposição os testículos após a incisão,

(D). Fonte: Própria
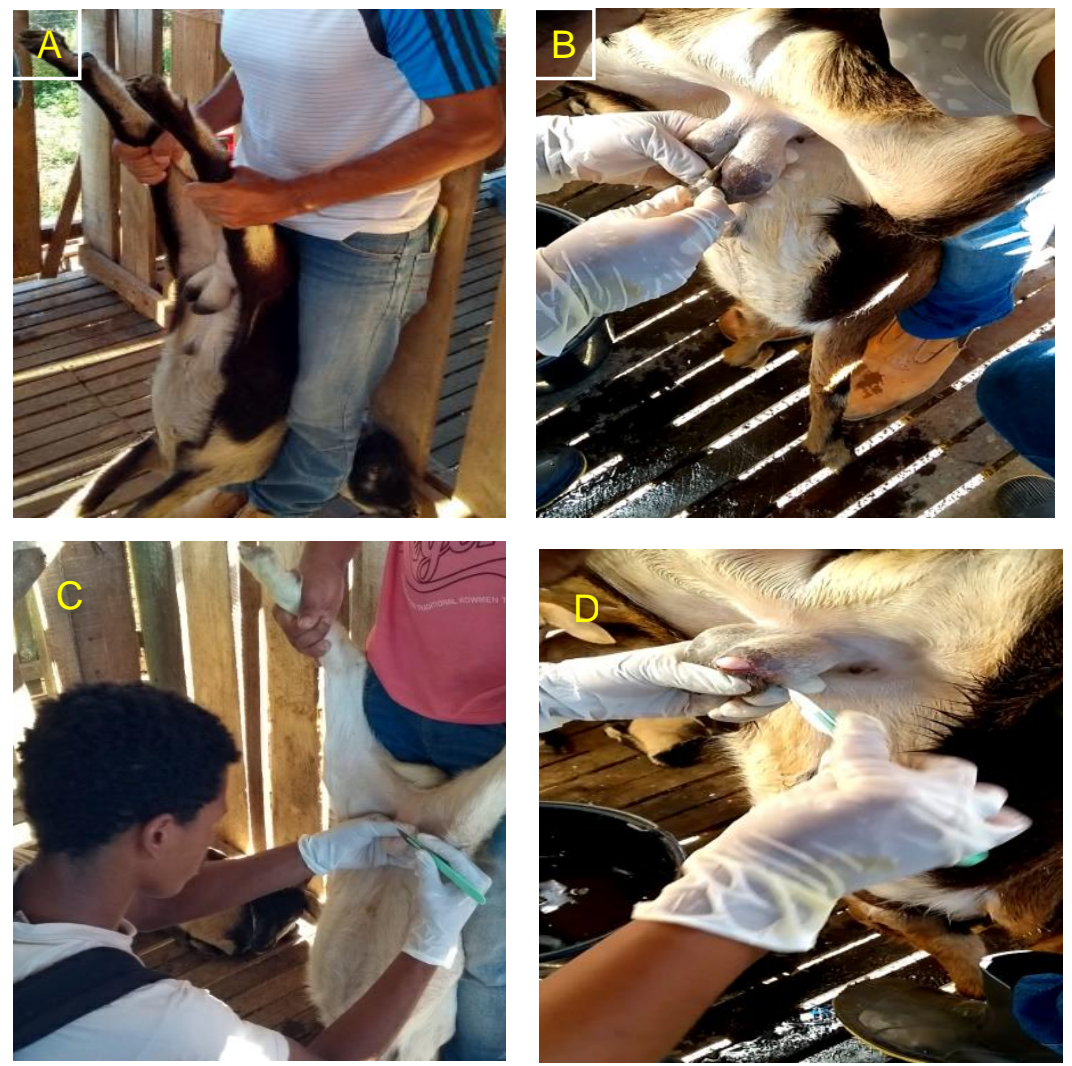

\section{CONSIDERAÇÕES}

A aula prática mostrou todo o procedimento ministrado pelo professor em sala de aula, pois foram abordadas as etapas de como castrar tirando as dúvidas de muitos alunos, deixando todos bem a vontade com o procedimento e fazer tudo técnica correta para que não tenha erro.

As práticas de manejo como a castração, podem ser utilizadas para melhorar a produção de carne e permitir uma oferta continuada ao longo do ano, atendendo aos padrões de qualidade estabelecidos pelo mercado consumidor e adequado as suas necessidades produtor.

Porém, com a evolução na produção desses ruminantes, podem-se obter animais prontos para o abate precocemente, diminuindo o emprego da castração na produção de ovinos e caprinos. 


\section{REFERÊNCIAS}

ANDRADE, E. Influência da castração com diferentes métodos e idade no desenvolvimento ponderal e sabor da carne de caprinos. 2000. Disponível em:<http://www.holistica.com.br/evangi/castracao.shtml>. Acesso em 26 mar.2009.

BRAGA, Z. C. A. C., BRAGA, A. P. \& VASCONCELOS, S. H. L. Efeito da castração sobre ganho de peso e características da carcaça de caprinos SRD. Caatinga, Mossoró-RN, 16(1/2): 13- 15, dez. 2003.

CARVAlHO, S., PIVATO, J. , VERGUEIRO, A., KIELING, R. \& TEIXEIRA, R. C. . Desempenho e características quantitativas da carcaça de cordeiros da raça Suffolk, castrados e não castrados, terminados em confinamento. Rev Bras Agrociência. Pelotas-RS, v. 11, n. 1, p. 78-84, 2005. 